\title{
A review on stem cell therapy for multiple sclerosis: special focus on human embryonic stem cells
}

This article was published in the following Dove Press journal:

Stem Cells and Cloning:Advances and Applications

\section{Geeta Shroff \\ Department of Stem Cell Therapy, Nutech Mediworld, New Delhi, India}

Correspondence: Geeta Shroff Nutech Mediworld, H-8, Green Park Extension, New Delhi II0016, India Tel +9| | | 26180039

Fax +9| || 26560089

Email geetashroff@hotmail.com

\begin{abstract}
Multiple sclerosis (MS), a complex disorder of the central nervous system (CNS), is characterized with axonal loss underlying long-term progressive disability. Currently available therapies for its management are able to slow down the progression but fail to treat it completely. Moreover, these therapies are associated with major CNS and cardiovascular adverse events, and prolonged use of these treatments may cause life-threatening diseases. Recent research has shown that cellular therapies hold a potential for CNS repair and may be able to provide protection from inflammatory damage caused after injury. Human embryonic stem cell (hESC) transplantation is one of the promising cell therapies; hESCs play an important role in remyelination and help in preventing demylenation of the axons. In this study, an overview of the current knowledge about the unique properties of hESC and their comparison with other cell therapies has been presented for the treatment of patients with MS.
\end{abstract}

Keywords: multiple sclerosis, stem cells, human embryonic stem cells, remyelination, axonal loss, neurological disorder

\section{Introduction}

Promising advances have been made in the recent years in stem cell transplantation to treat and cure damaged tissues, injuries, and various diseases. This is especially true with the various autoimmune disorders, specifically for the ones which are associated with nervous system, where damage often appears from the degeneration of cells. ${ }^{1}$

Treatment using cell therapy involves a form of immune suppression but unlike standard immune-based drugs, it is designed to reset rather than suppress the immune system. Scientists define three ways to use stem cell therapy: the first involves the use of stem cells to replace damaged myelin-forming oligodendrocytes within the central nervous system (CNS); ${ }^{2,3}$ the second aims to replace the individual's malfunctioning immune system, making use of hematopoietic stem cells (HSCs); ${ }^{4,5}$ and the third seeks to utilize the endogenous stem cell populations by mobilization with or without in vitro expansion, exploiting their reparative and neuroprotective properties. ${ }^{6,7}$

Studies have been carried out for various type of stem cells: autologous hematopoietic stem cells (AHSCs), mesenchymal stem cells (MSCs), neural stem cells (NSCs), induced pluripotent stem cells (iPSCs), and human embryonic stem cells (hESCs). ${ }^{8}$

$\mathrm{hESC}$ transplantation is a controversial yet a powerful strategy for the treatment of patients with autoimmune diseases. hESC lines can differentiate into neural precursor cells and neurons, astrocytes, and oligodendrocytes that show their potential in treating several incurable neurological disorders like spinal cord injury, ${ }^{9,10}$ cerebral palsy, ${ }^{11}$ 
multiple sclerosis (MS), ${ }^{12}$ Parkinson's disease,${ }^{13}$ and many more. The remarkable properties of hESC therapy in treating various terminal conditions both in vitro and in vivo could be used as the first-line therapy in the future. ${ }^{14}$

Of the various neurological diseases, MS is one of the most complicated in which the underlying pathological mechanism remains unclear, and the incompetence of a large number of promising treatments for the disease makes it an ideal target for use in regenerative medicine. ${ }^{15}$ Pluripotency, self-renewal, and ability to regenerate and differentiate into neuronal cells are the promising factors to use hESCs in treating MS. These properties make them an ideal resource of unlimited supply of neural derivatives. ${ }^{16,17}$ This review provides an account on the role of hESC lines in treating MS and their comparison with other cellular therapies. Subsequently, this will discuss the development of hESC line at the Department of Stem Cell Therapy, Nutech Mediworld, India that has been able to treat various terminal diseases.

\section{MS and its pathogenesis}

MS is a chronic inflammatory demyelinating disease of the CNS which involves the loss of myelin-forming oligodendrocytes that can be followed by a spontaneous and an efficient regenerative process called remyelination. ${ }^{18}$ It affects the people of almost all the ages in many parts of the world, mostly young people, especially more prevalent in women, and among those in northern latitudes. Relapsing-remitting multiple sclerosis (RRMS) is the most common form of MS. The disease course is biphasic; initially, there are alternating episodes of acute neurological deficits or worsening episodes of relapses followed by a complete or partial recovery (i.e., remission). Within a span of $15-20$ years, most (70\%) of the patients with RRMS develop secondary progressive MS which is characterized by a progressive neurological decline independent of relapses (inflammation) ${ }^{19}$ MS has a genetic susceptibility, but it is not directly inherited..$^{20}$ The disease has an unknown etiology with no cure; only symptomatic treatment is available. ${ }^{21,22}$

\section{Current treatment approach for MS and their limitations}

Since 2010, various oral therapies were approved which offer added convenience, but all these therapies provided only symptomatic relief. ${ }^{22,23}$ The currently available treatments mainly target the underlying immunologic etiology of MS. Most of the therapies are composed of medications that are either immunomodulatory or immunosuppressive and are aimed at reducing the frequency and intensity of the relapses. These treatments are undoubtedly quite efficient in preventing the frequency of relapses but are not able to make up the axon damage loss, further progression of disease, and irreversible disability. ${ }^{24}$ Current disease modifying therapies (DMTs) including interferons, ${ }^{25}$ immunosuppressants, ${ }^{26}$ corticosteroids, ${ }^{27}$ and monoclonal antibodies ${ }^{28}$ mainly target the cells and mediators of the adaptive immune system which are the triggering factors to cause the immune response to elicit the disease; however, this only helps to slow down the progression. Also, these treatments lack in providing the neuroprotective benefits to the patients, resulting in further damage/loss..$^{24,29}$

The treatment for MS is expensive. With the progression of the disease and increasing disability level, there has been a further increase in the direct and indirect costs involved. This increment in cost is generally related to relapses and productivity costs rather than the direct cost involved in using DMTs. ${ }^{30,31}$ Direct and indirect health care costs range from US\$8,528 to $\$ 54,244$ per patient per year in the US. MS ranks second only to congestive heart failure in terms of price when compared with other chronic conditions. ${ }^{32}$ First-generation DMTs, originally costing US $\$ 8,000$ to $\$ 11,000$, now cost about US $\$ 60,000$ per year. Newer DMTs commonly entered the market with a cost $25 \%-60 \%$ higher than existing DMTs. ${ }^{33}$

\section{Cellular therapies in MS}

Generally for most of the stem cell therapies, the first approach to treat MS is to start with high dose of immunosuppressants followed by stem cell transplantation. The rationale behind this approach is that immunosuppression helps to eliminate autoreactive $\mathrm{T}$ and $\mathrm{B}$ cells, therefore allowing installation of new and tolerant immune system. ${ }^{34}$

Despite the standard therapies that are available for MS, majority of the patients eventually enter a secondary progressive phase for which no therapy has demonstrated efficacy. Reversible relapses due to the potent compensatory mechanisms in the brain, which cause extensive axonal loss and demyelination, are the bottlenecks of this disease. Remyelination is one of the strategies to recover the damage and prevent the further relapses. ${ }^{35,36}$ It is a regenerative process by which demyelinated axons are reinvested with new myelin sheaths. Spontaneous and robust remyelination occurs at the early stages of MS. ${ }^{29}$

Stem cell therapy is an effective therapy in regeneration medicine and a new approach to overcome the limitations of currently available therapies. Stem cell treatment is now available all over the world to treat MS. However, 
the cost of treatment varies in every country as per its own regulations and policies. In US, the average cost per treatment is US\$7,000 to $\$ 10,000$. Costs for treatments outside of the US are usually far higher than in the US, ranging from US $\$ 20,000$ up to $\$ 100,000 .{ }^{37,38}$ A cost-effectiveness survey of AHSC transplantation for MS treatment in the UK conducted by Tappenden et al reported that the cost-effectiveness of AHSC transplantation is expected to be around $£ 2,800$ per additional quality-adjusted life year gained. ${ }^{39}$ Table 1 shows the various stem cell studies in MS.

\section{Different cellular therapies and their mechanism of actions in treating neurological disorders}

Studies have been carried out for various types of stem cells: HSCs, adult stem cells that are found in bone marrow and blood; MSCs, adult stem cells found in several places in the body, including the bone marrow, skin, and fat tissue; NSCs, specialized stem cells responsible for repairing nerve-insulating myelin in the brain. These can be derived from other types of stem cells such as MSCs, iPSCs (engineered from adult cells to produce many types of cells), and hESCs (stem cells derived from donated embryos that can naturally produce every type of cell in the body). ${ }^{8}$

\section{Autologus hematopoietic stem cell treatment}

High-dose immunosuppression followed by autologus hematopoietic stem cell treatment has been investigated in the past years as treatment for MS patients who are refractory to first-line therapy. The treatment is based on the rationale "high-dose immunosuppression is able to eliminate autoreactive $\mathrm{T}$ and $\mathrm{B}$ cells, therefore allowing installation of a new and tolerant immune system." 40,41 It uses harvested stem cells to reset patients' immune systems and reverse some of the symptoms of MS. During the treatment, bone marrow stem cells are collected from patient's blood and are frozen. These "HSCs" are at an early stage of development and lack the flaws that trigger MS. The faulty immune system is then destroyed using chemotherapy. The thawed-out stem cells are reinfused into the blood to reboot the immune system. ${ }^{42}$

\section{MSCs}

Immunomodulatory effects of MSCs include suppression of $\mathrm{T}$ cell proliferation, induction of regulatory $\mathrm{T}$ cells, influencing dendritic cell maturation and function, suppression of B-cell proliferation and terminal differentiation, and inhibition of natural killer cell function. Yamout et al reported that intrathecal administration of ex vivo-expanded autologous bone marrow-derived MSCs showed therapeutic benefit in 10 patients with advanced MS. ${ }^{43}$

\section{NSCs}

Remyelination is the regenerative process by which demyelinated axons are reinvested with new myelin sheaths. NSCs in the adult brain differentiate into oligodendrocytes in a context-specific manner and get involved in the remyelination of MS patients. NSCs may exert their beneficial effects not only through oligodendrocyte replacement but also by providing trophic support and immunomodulation, a phenomenon now known as "therapeutic plasticity." For the NSC therapy to be successful in MS, the cells need to be plastic enough to accommodate and survive in the nonpermissive inflammatory environment. ${ }^{24}$ In the adult CNS, tissue-specific germinal niches, such as the subventricular zone of the lateral ventricles and the subgranular zone of the dentate gyrus of the hippocampus, contain multipotent NSCs which have the capacity of self-renewal and differentiation into functional neurons and glial cells. ${ }^{44,45}$

\section{Induced pluripotent stem cells}

These cells can be differentiated into oligodendrocyte precursor cells (OPCs) which are essential to prevent axonal and subsequent retrograde neuronal degeneration in demyelinating lesions in MS. Studies conducted by Thiruvalluvan et al in non-human primate model showed that human-induced pluripotent stem cell (hiPSC)-derived OPCs migrate toward the MS-like lesions in the corpus callosum where they myelinate the denuded axons; this new approach indicates the potential use of hiPSC-derived OPCs for progressive forms of MS. ${ }^{46}$ The therapeutic potential of iPSCs has been extensively assessed by transplantation of iPSC-derived specific cells into different animal disease models. ${ }^{47,48}$ Safety and efficacy are the most important concerns for clinical development of iPSCs, as certain cells derived from iPSCs have tendency to elicit antigen-specific immune rejection responses after transplantation into the autologous recipients. ${ }^{49,50}$

\section{hESCs}

The remarkable properties of hESCs have shown their clinical usefulness over the other stem cells studied. hESC-based therapies can give rise to specific specialty cells such as dermatomes from undifferentiated ESCs or incompletely differentiated neural cell. hESCs provide immunosuppressive neuroprotective mechanism. ${ }^{51}$ Research on hESCs is obligated 
Table I Studies using stem cells to treat MS

\begin{tabular}{|c|c|c|c|}
\hline Type of stem cells & Authors, year & Preclinical/clinical & Key objectives and findings \\
\hline $\begin{array}{l}\text { Neural stem cells } \\
\text { (NSCs) - glial cells }\end{array}$ & $\begin{array}{l}\text { Haffernan et al, } \\
2012^{90}\end{array}$ & $\begin{array}{l}\text { Clinical human } \\
\text { model }\end{array}$ & $\begin{array}{l}\text { The study involved the designing of CPP sequence that selectively transduced } \\
\text { human glial cells (excluding nonglial cell types), and conducted preliminary } \\
\text { screens of purified, recombinant CPPs with immature and matured human } \\
\text { oligodendrocytes and astrocytes and two nonglial cell types to treat MS. }\end{array}$ \\
\hline $\begin{array}{l}\text { Embryonic stem cells } \\
\text { derived NSCs }\end{array}$ & $\begin{array}{l}\text { Payne et al, } \\
2012^{91}\end{array}$ & $\begin{array}{l}\text { Preclinical mouse } \\
\text { model }\end{array}$ & $\begin{array}{l}\text { The study evaluated the therapeutic potential of NSCs derived from ES cells } \\
\text { by two different neural differentiation protocols that utilized adherent culture } \\
\text { conditions and compared their effect with primary NSCs derived from the } \\
\text { subventricular zone (SVZ). }\end{array}$ \\
\hline $\begin{array}{l}\text { Hematopoietic stem } \\
\text { cells (HSCs) }\end{array}$ & $\begin{array}{l}\text { Fassas and } \\
\text { Kazis, 2003 }\end{array}$ & $\begin{array}{l}\text { Clinical Phase I and } \\
\text { Il studies in human }\end{array}$ & $\begin{array}{l}\text { The study was based on concept of immune ablation by high-dose therapy } \\
\text { and reconstitution of normal immunity from transplant-derived lymphocyte } \\
\text { progenitors. It gave way to the concept of "resetting" the immune system and of } \\
\text { bringing the disease to a lower level of activity. }\end{array}$ \\
\hline $\begin{array}{l}\text { ¡PSC-derived neural } \\
\text { progenitor cells } \\
\text { (NPCs) }\end{array}$ & $\begin{array}{l}\text { Nicaise et al, } \\
2007^{92}\end{array}$ & $\begin{array}{l}\text { iPS cell lines were } \\
\text { obtained from } \\
\text { humans and NPCs } \\
\text { were obtained from } \\
\text { mice models }\end{array}$ & $\begin{array}{l}\text { The study involved comparison of treating PPMS cases with NPCs and iPS- } \\
\text { derived NPCs. The results showed that NPCs from PPMS cases provided no } \\
\text { neuroprotection against active CNS demyelination compared to NPCs from } \\
\text { control iPS lines which were capable of completely preventing injury. }\end{array}$ \\
\hline $\begin{array}{l}\text { Neural precursor } \\
\text { stem cells (NPSCs) }\end{array}$ & $\begin{array}{l}\text { Donega et al, } \\
2014^{93}\end{array}$ & $\begin{array}{l}\text { Preclinical mouse } \\
\text { model }\end{array}$ & $\begin{array}{l}\text { The study involved injecting NPSCs in mice model of experimental autoimmune } \\
\text { encephalomyelitis (EAE), via iv and icv route of administration, with chronic CNS } \\
\text { inflammatory demyelination, and envisage the systemic stem cell delivery as a } \\
\text { valuable technique for the selective targeting of the inflamed brain in regenerative } \\
\text { neurology. }\end{array}$ \\
\hline $\begin{array}{l}\text { Autologus } \\
\text { hematopoietic stem } \\
\text { cells (AHSCs) }\end{array}$ & $\begin{array}{l}\text { Chen et al, } \\
2012^{5}\end{array}$ & $\begin{array}{l}\text { Clinical human } \\
\text { studies }\end{array}$ & $\begin{array}{l}\text { This was a retrospective evaluation for the safety and long-term clinical outcome } \\
\text { of AHSC therapy in MS patients in China. Twenty-five patients with various types } \\
\text { of MS were treated with AHSC therapy. Peripheral blood stem cells were derived } \\
\text { by leukapheresis after mobilized with granulocyte colony-stimulating factor. Then } \\
\text { CD34+ cell selection of the graft was performed and anti-thymocyte globulin was } \\
\text { given for T-cell depletion, with the conditioning regimen BEAM adopted and early } \\
\text { and late toxicities recorded. Long-term responses were evaluated by the expanded } \\
\text { disability status scale (EDSS), progression-free survival, and gadolinium-enhanced } \\
\text { magnetic resonance imaging scans. Ten, seven, and eight patients experienced } \\
\text { neurological improvement, stabilization, and progression, respectively. }\end{array}$ \\
\hline $\begin{array}{l}\text { Mesenchymal stem } \\
\text { cells (MSCs) }\end{array}$ & $\begin{array}{l}\text { Al Jumah et al, } \\
2012^{94}\end{array}$ & $\begin{array}{l}\text { Preclinical: EAE } \\
\text { mouse model }\end{array}$ & $\begin{array}{l}\text { The study evaluated the immunomodulatory and neuroprotective effects of } \\
\text { MSCs in EAE for MS. The study concluded that MSCs can rescue neural cells } \\
\text { via a mechanism that is mediated by soluble factors, which provide a suitable } \\
\text { environment for neuron regeneration, remyelination, and cerebral blood flow } \\
\text { improvement. }\end{array}$ \\
\hline $\begin{array}{l}\text { Autologous MSCs - } \\
\text { bone marrow- } \\
\text { derived cells }\end{array}$ & $\begin{array}{l}\text { Connick et al, } \\
2012^{95}\end{array}$ & $\begin{array}{l}\text { Clinical human } \\
\text { studies }\end{array}$ & $\begin{array}{l}\text { This was an open label phase } 2 \mathrm{a} \text { proof of concept study in patients with secondary } \\
\text { progressive MS with characteristic visual pathways (expanded disability status } \\
\text { score: } 5.5-6.5 \text { ). The intravenous infusion of autologous bone marrow-derived } \\
\text { MSCs were injected, and after the period of } 10 \text { months, improvement was noted } \\
\text { after treatment in visual acuity (difference in monthly rates of change }-0.02 \\
\text { logMAR units, } 95 \% \mathrm{Cl}:-0.03 \text { to }-0.0 \mathrm{I} ; p=0.003 \text { ) and visual evoked response } \\
\text { latency }(-1.33 \mathrm{~ms}, 95 \% \mathrm{Cl}:-2.44 \text { to }-0.2 \mathrm{I} ; p=0.020 \text { ), with an increase in optic } \\
\text { nerve area (difference in monthly rates of change } 0.13 \mathrm{~mm}^{2}, 95 \% \mathrm{Cl}: 0.04 \text { to } \\
0.22 ; p=0.006 \text { ). There were no significant effects on color vision, visual fields, } \\
\text { macular volume, retinal nerve fiber layer thickness, or optic nerve magnetization } \\
\text { transfer ratio. }\end{array}$ \\
\hline $\begin{array}{l}\text { Embryonic-derived } \\
\text { oligodendrocyte } \\
\text { progenitor } \\
\text { cells (OPCs) - MSCs }\end{array}$ & $\begin{array}{l}\text { Cristofanilli } \\
\text { et al, 2011 }{ }^{96}\end{array}$ & $\begin{array}{l}\text { Preclinical mice } \\
\text { model }\end{array}$ & $\begin{array}{l}\text { The study investigated the effect of syngeneic MSCs on the survival and } \\
\text { remyelination abilities of allogeneic OPCs in adult non-immunosuppressed shiverer } \\
\text { mice. At all time points examined, cotransplantation with MSCs increased OPC } \\
\text { engraftment, migration, and maturation in myelinating oligodendrocytes, which } \\
\text { produced widespread myelination in the host corpus callosum. In addition, MSCs } \\
\text { reduced microglia activation and astrocytosis in the brain of transplanted animals } \\
\text { as well as T-cell proliferation in vitro. }\end{array}$ \\
\hline
\end{tabular}

Abbreviations: CPP, cell penetrating peptides; MS, multiple sclerosis; ES, embryonic stem; PPMS, primary progressive multiple sclerosis; CNS, central nervous system; iv, intravenous; icv, intracerebroventricular; logMAR, logarithm of the minimum angle of resolution; BEAM, BCNU, etoposide, arabinosylcytosine, melphalan. 
as there is a limitation in the preparation of sufficient human OPCs to get tissue-specific progenitor cells, though some preclinical studies have tried to differentiate mouse ESCs (mESCs) into oligodendrocyte with myelogenic properties. ${ }^{52,53}$ Aharonowiz et al transplanted hESC-derived neural progenitors into the mice with experimental autoimmune encephalomyelitis. Histological evaluation revealed that the transplanted neural progenitors migrate to the mice brain, especially to the host white matter. However, remyelination and production of mature oligodendrocytes were not clearly observed. ${ }^{54}$

\section{How do hESCs work in treating neurological disorders?}

For the therapeutic action of the cells, it is necessary that the transplanted cells should reach the target site or the site of injury, also referred to as "homing." Although, no study till date has assessed the mechanism of action of hESCs, various hypotheses have been suggested and discussed to explain the mechanism of action of hESCs for treating MS and other autoimmune disorders (Figure 1), which are discussed in the following section.

\section{Differentiation}

Human ESCs differentiate efficiently to form trophoblast, the outer layer of the placenta that mediates implantation and connects the conceptus to the uterus. hESCs have also been observed to differentiate into cells expressing genes characteristic of germ cells. ${ }^{55-57}$ In particular, the ability of hESCs to differentiate into defined neural lineages, neurons, astrocytes, and oligodendrocytes is a fundamental characteristic that has been exploited for the treatment of neurological disorders. ${ }^{58,59}$

The studies also observed that the transplanted stem cells act by combining with local stem cells in the injured tissue to accomplish the healing process. Liu et al reported that the immune system of the patient releases signals (interferon [IFN]- $\gamma$ and TNF- $\alpha$ ) to communicate with the transplanted MSCs during the repair of the injured tissue. Thus, the stem cells get attracted to the site of injury. ${ }^{60}$ Other studies identifying the homing of MSCs to the target site via the SDF-1/ CXCR4 pathway reported that SDF-1, a chemoattractant, is released by the injured tissue which attracts the transplanted stem cells. ${ }^{61,62}$ VEGF is another key mediator of mobilization. ${ }^{63}$ It is hypothesized that hESCs might follow the same pattern to migrate to the target site and initiate regeneration and repair processes. Angiogenesis, improving cerebral blood flow to treat the neurological disorder, is another mechanism by which hESCs work. The more likely mechanisms of action include the release of VEGF and increase in the endogenous levels of other factors (such as brain-derived neurotrophic factor and fibroblast growth factor) that play a role in neovascularization. ${ }^{64}$

Various studies of cell transplantation have reported the mechanism of angiogenesis to treat the disorders. Studies conducted by Taguchi et al had reported that systemic administration of human cord blood-derived CD34+ cells to immunocompromised mice subjected to stroke 48 hours earlier induced neovascularization in the ischemic zone and provided a favorable environment for neuronal regeneration. ${ }^{65}$

\section{Reduced apoptosis and release of trophic factors}

The neuroprotective response is elicited by cell transplantation by rescuing the apoptotic cells, particularly in penumbral tissue. This is mediated by the secretion and upregulation of certain trophins, such as basic fibroblast growth factor, brainderived neurotrophic factor, VEGF, glial cell-line-derived factor, and nerve growth factor. It helps in reducing apoptosis in injured tissue and aids in neurological recovery. ${ }^{66}$

\section{Reduced inflammation}

Immunomodulatory effects of the transplanted cells play a major role in neuroprotection by reducing infiltration of macrophages and microglial activation and inhibiting T- cell activation. Preclinical studies have shown evidence for upregulation of anti-inflammatory cytokines and attenuation of expression of proinflammatory cytokines in both ischemic and hemorrhagic stroke. ${ }^{67,68}$

\section{Small size}

Another remarkable characteristic is that these cells are very small in size $(<1 \mu \mathrm{m})$ and have very high multiplication rate. Their small size makes it possible for them to cross the blood-brain barrier and reach the target sites easily. These cells resemble and behave like previously very small embryonic stem cells. ${ }^{43}$

\section{Comparison of other cellular therapies with hESCs}

Current cellular therapies for MS are largely palliative, not curative. MSCs are regenerative and immunosuppressive, indicating a potential therapy for MS, yet the variability and low potency of MSCs from adult sources hinder their therapeutic potential. Similarly, NSCs and neural progenitor cells (NPCs) are associated with limitations of appropriate microenvironment needed for differentiation into oligodendrocytes. Various studies have reported the neuroprotective and immunomodulatory effects of transplanted exogenous 


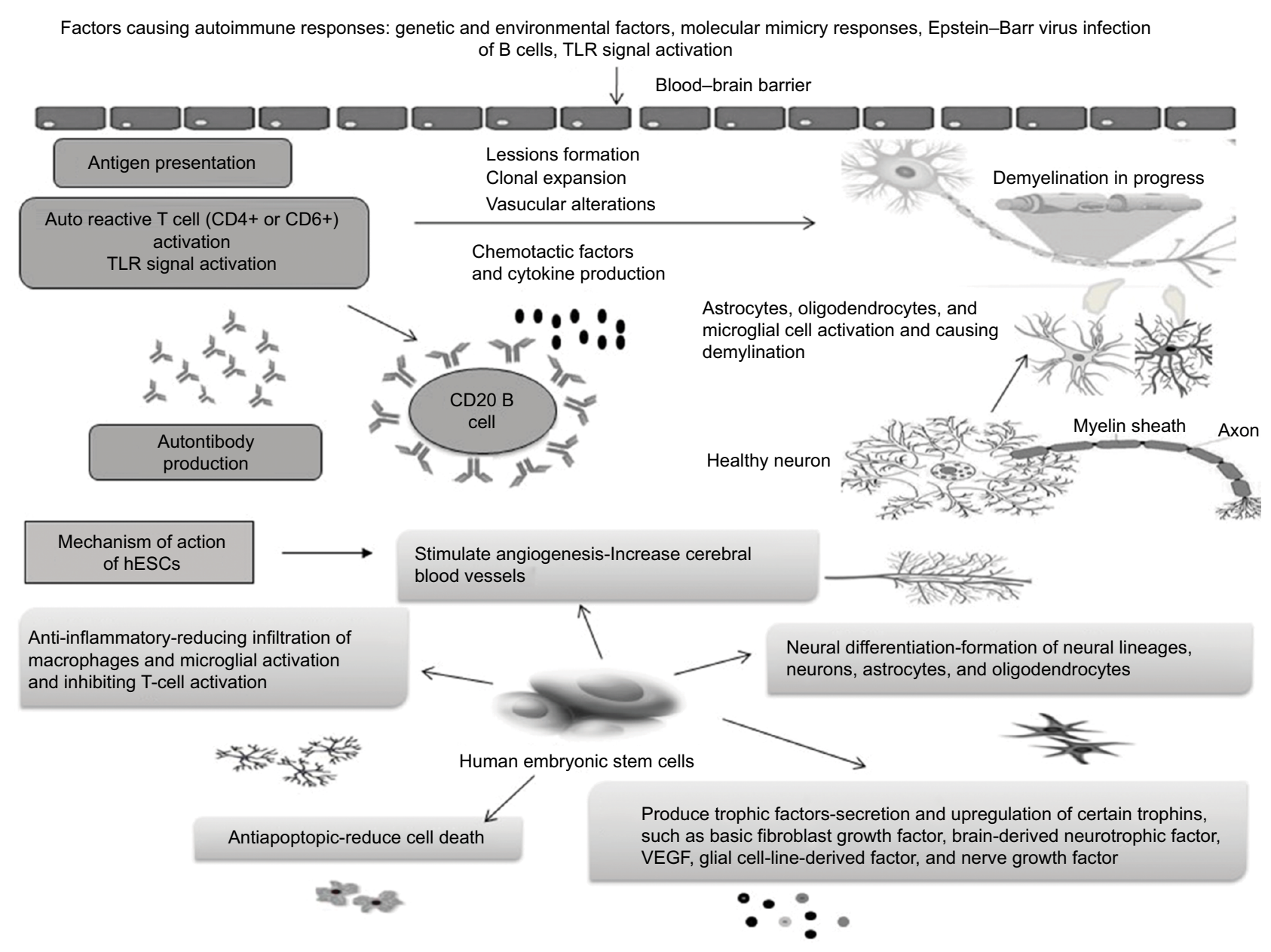

Figure I Factors causing multiple sclerosis and other autoimmune disorders and mechanism of action of hESCs in treating neurological disorders. Abbreviation: hESCs, human embryonic stem cells.

NSCs on T-cell activation, microglial activation, and endogenous remyelination and their effects on the pathological process and prognosis in animal models of MS. ${ }^{24}$ However, a lack of neural progenitor sources and immune rejection are the two hindrances restricting the development of this new MS treatment strategy. HSCs are obtained from bone marrow, peripheral blood, or umbilical cord blood. They are suitable for both autologous as well as allogeneic use, but are associated with the issues regarding consistency of numbers and potency of cells obtained from the bone marrow, as well as the need for ex vivo expansion of cells when using umbilical cord blood as the source. ${ }^{69}$

The therapeutic potential of iPSCs has been studied in various animal models. However, at the same time, there is a risk of tumor formation due to the residual undifferentiated iPSCs. ${ }^{47,48}$ Also, some studies reported the cases of antigenspecific immune rejection responses after transplantation into the autologous recipients..$^{49,50}$
hESCs have shown substantial results in treating MS than stem cells derived from adult bone marrow. A recent research conducted by Wang et al, where they compared eight lines of adult bone marrow stem cells to four lines of hESCs, showed that all of the bone marrow-related stem cells expressed high levels of a protein molecule called cytokine that stimulates autoimmunity and can worsen the disease, whereas all of the hESC-related lines expressed low levels of the inflammatory cytokine. ${ }^{70}$

hESC therapy is not only a safe, effective, and efficient treatment for MS, but is also a cost-effective treatment with better results of recovery. Since remyelination is an irreversible process, the frequency of relapses is quite low or negligible as compared to the conventional therapies where the treatment has to be continued for rest of the life of patient. Comparatively, hESC treatment is generally a one-time treatment plan, and the patient gets rid of further relapses with single use of therapy. 


\section{hESC cell line developed at our institute and its uniqueness}

The hESC line at our institute was developed using patented technology (United States patent US 8592, 208, 52) in a good manufacturing practice, good laboratory practice, and good tissue practice compliant laboratory (United States patent WO 2007/141657A PCT/1B 2007, 2007 Dec 13). ${ }^{71}$

The cell lines used in our study were obtained from a single fertilized egg after $24-48$ hours of fertilization. Since a single fertilized egg is able to provide therapeutic amounts of $\mathrm{hESCs}$ and/or their derivatives to treat multitudes of patients, there was no repeated exploitation of human embryos, and the number of ethical issues associated with the use of hESC therapy could be avoided. The use of hESCs at our institute has also been accepted and confirmed by the House of Lords, Regenerative Medicine, Science, and Technology Committee. $^{72}$

\section{Xeno-free culture medium and appropriate size}

While maintaining the culture conditions of $h E S C s$, there are chances of chromosomal aberrations, which are difficult to recognize by conventional karyotypic analysis techniques. These chromosomal alterations seem to be more common when hESCs are grown in feeder-free conditions and maintained using enzymatic rather than mechanical dissociation methods. ${ }^{73-75}$ The culture media used was free of any antioxidants, growth factors, insulin or insulin substitutes, collagen precursors or collagen precursor substitutes, residues or "conditioned media," trace elements, animal products, and feeder cells. The absence of any xeno-product makes it suitable for clinical cell therapy. The cells thus obtained are very small in size $(50 \mathrm{~nm}-2.5 \mu \mathrm{m})$ and procured 24 hours after fertilization. ${ }^{71,76}$

\section{Unique characterization}

The cell lines obtained at our institute harbor all the properties of hESCs and blastocysts and express PSC markers like octamer-binding transcription factor 4, (sex determining region Y)-box 2, Nanog, stage-specific embryonic antigen-4, trophoectoderm marker; keratin 18 , beta-human chorionic gonadotropin (negative), immune-regulatory marker; human leukocyte antigen $\mathrm{G}$ (negative), gene activating marker 5 -methylcytosine, and other markers like telomerase and $\alpha$ fetoprotein. ${ }^{76}$

\section{Genomic stability and cell viability}

Nonenzymatic passaging method was used and regular checks on spontaneous differentiation were conducted. All these considerations have resulted in maintenance of stable cell lines over the years on repeated passaging. These cell lines are in clinical use for more than 14 years and have undergone $>4,000$ passages. The cell lines have been characterized at cellular, molecular, and functional levels and established for its safety and efficacy. These have been evaluated for their viability as well as genomic integrity. A special cryopreservation technique was used where a relatively low concentration of DMSO $(0.2 \%-2 \%)$ has been used, which is helpful in preventing any possible toxicity to patients. Our analyses of viability of these cells showed that $95 \%$ of the cells were alive after being thawed for more than 9 years..$^{76,77}$

\section{No immune rejections}

Most of the previous studies have targeted either four single blastomeres (four-cell and five-cell stage) or morula embryos (eight-cell stage) as a source to derive hESCs. ${ }^{78-80}$ hESCs prepared at our institute are unique in their procedure of development, are harvested at very initial stage of blastocyst formation, i.e., two-celled stage blastocyst, post-pronuclear fertilization and first cell division, a stage at which cells initiate to differentiate or rather are in the transition phase and do not acquire any antigenic property. At this embryonic stage of harvesting, genesis is not activated, thus these cells are safe for transplantation which declines the risks of immune rejection. ${ }^{71}$

\section{Other clinical applications}

The cell lines have been used safely in various clinical applications including neurological disorders such as MS, Parkinson's disease, cerebral palsy, Friedrich ataxia, amyotrophic lateral sclerosis, Duchenne muscular dystrophy, Lyme disease, autism, traumatic brain injury, and many more. ${ }^{81-87}$ Table 2 presents the summary of our hESC lines used in various clinical applications and their results in patients.

\section{hESC lines used in MS}

The cells are of two types: predominantly neuronal and nonneuronal (mesenchymal, ocular, germ, etc.) progenitor cells with their undifferentiated states. This study was performed on the generation of different neuronal cells from an $\mathrm{hESC}$ line produced from biopsied blastomeres at the two-celled cleavage stage from a discarded embryo during an in vitro fertilization process. The differentiation of neuronal cells by determining the lineage-specific neuronal marker, Neu $\mathrm{N}$, was also explored. It was found that these multipotent NPCs differentiated into all three types of cells of the nervous 
Table 2 Clinical applications of our hESC lines in other neurological disorders

\begin{tabular}{|c|c|c|}
\hline Clinical application & Type of study & Results \\
\hline Cerebrovascular accident & Case series $(2015)^{97}$ & $\begin{array}{l}\text { Twenty two patients were evaluated for improvement on the basis of European Stroke } \\
\text { Scale (ESS) at baseline and at the end of each treatment period. A total of } 22 \text { patients } \\
\text { were included and all received intensive dosing with hESCs. All affected patients showed } \\
\text { an improvement in gait ( } 22 \text { patients), speech (I } 5 \text { patients), level of consciousness (two } \\
\text { patients), comprehension and gaze (one patient each) by at least one point at the end of } \\
\text { T6. In addition, patients showed improvement in walking, balance (sitting and standing), } \\
\text { and spasticity after receiving hESC therapy. Overall, II patients ( } 50 \% \text { ) experienced adverse } \\
\text { events (AEs) during the study. No serious adverse events (SAEs) and deaths were reported. } \\
\text { Conclusion: All the patients showed improved cognitive skills and regained their functional } \\
\text { ability. No severe AEs or SAEs were reported during the study. hESC therapy was well } \\
\text { tolerated among all the patients included in the study. }\end{array}$ \\
\hline Parkinson's disease & Case report $(2015)^{98}$ & $\begin{array}{l}\text { The study was on a } 65 \text {-year-old patient suffering with Parkinson's disorder. With the help } \\
\text { of hESC treatment, the patient showed significant improvement in his health following the } \\
\text { treatment, such as reduction in tremors, bradykinesia, muscle rigidity, pain and stiffness in } \\
\text { the neck, shoulder and low back, and improvement in the range of movements of the neck. } \\
\text { The patient was able to balance himself while walking, and had reduction in numbness in his } \\
\text { left hand and both of his legs. He was able to speak louder and had improved writing skills. } \\
\text { No AE or teratoma formation was observed. }\end{array}$ \\
\hline Spinocerebellar ataxia & Case series $(2015)^{99}$ & $\begin{array}{l}\text { This was a case study of three patients. All received hESC treatment for } 2 \text { years. After } \\
\text { therapy, all showed improvement in overall stamina, endurance, coordination, sitting } \\
\text { balance, standing and walking ability, speech, and flexibility. There was a reduction in } \\
\text { tremors and no head nodding was observed. }\end{array}$ \\
\hline \multirow[t]{2}{*}{ Cerebral palsy (CP) } & Case series $(2015)^{82}$ & $\begin{array}{l}\text { The study included two patients suffering from } \mathrm{CP} \text {, after undergoing treatment with hESC } \\
\text { therapy. The treatment consisted of phases in which } 0.25 \mathrm{~mL} \text { of hESCs ( }<4 \text { million cells) was } \\
\text { administered through intramuscular route once daily and I mL of hESCs ( }<16 \text { million cells) } \\
\text { was administered through intravenous route twice every } 7 \text { days. A marked improvement in } \\
\text { cognitive and motor functions was seen in the patients after the treatment. }\end{array}$ \\
\hline & $\begin{array}{l}\text { Retrospective study } \\
(2015)^{100}\end{array}$ & $\begin{array}{l}\text { The study included } 91 \text { patients; SPECT scan showed improved perfusion in all patients. } \\
\text { Cognitive skills improved in } 69 \% \text { of the patients; there were no seizures }(n=90) \text { and hearing } \\
\text { improvement was observed }(n=8) \text {. }\end{array}$ \\
\hline Multiple sclerosis (MS) & Case report $(2015)^{86}$ & $\begin{array}{l}\text { A case report of a 34-year-old female with MS. After treatment, tractography showed } \\
\text { a mild reduction in the size of lesions in bilateral periventricular white matter and in the } \\
\text { right occipital white matter. Improvement in muscle bulk, tone, and power had increased } \\
\text { energy level and power of upper limbs and gained weight. }\end{array}$ \\
\hline $\begin{array}{l}\text { MS and Lyme disease } \\
\text { (LD) }\end{array}$ & Case series $(2016)^{101}$ & $\begin{array}{l}\text { The study included one male ( } 42 \text { years) and one female ( } 30 \text { years) with both MS and LD. } \\
\text { The hESCs were administered via different routes to regenerate the injured cells. Both the } \\
\text { patients showed remarkable improvement in their functional skills, overall stamina, cognitive } \\
\text { abilities, and muscle strength. Furthermore, the improvements in the patients' conditions } \\
\text { were assessed by magnetic resonance tractography and SPECT. }\end{array}$ \\
\hline
\end{tabular}

Abbreviations: hESCs, human embryonic stem cells; SPECT, single photon emission computed tomography.

system, i.e., neurons, oligodendrocytes, and astrocytes, as observed under a phase contrast microscope. ${ }^{88}$

The uniqueness of these cells is that they are in a readyto-inject form and can be used in a number of otherwise incurable conditions. In patients with MS, hESC therapy was given as per the standard treatment protocol which included treatment phases (8-12 weeks) with gap phases (4 months) wherein $0.25 \mathrm{~mL}$ ( $<4$ million cells) of hESCs was administered intramuscularly twice a day to ensure that the recipient's immune system does not reject the stem cells ("prime" the body). About $1 \mathrm{~mL}$ of hESCs (<16 million cells) was administered every 10 days intravenously (to "home in" to the required area) and 1-5 $\mathrm{mL}$ of hESCs was administered every 7 days. It was observed that these hESC cell lines have the homing capability because of their therapeutic effect at the injured or inflamed tissue. After 2 months of treatment, patients showed remarkable improvement in overall stamina, muscle strength, functional skills, and cognitive abilities; the patients experienced an increased energy level and power of upper limbs. The body weight was also increased.

The radiological investigation using MRI and tractography suggested that there was a significant improvement in the condition of the patient. Tractography studies 
interpreted the extent of improvement in perfusion, which showed that there was a mild reduction in the size of lesions in bilateral periventricular white matter and another lesion in the right occipital white matter. The remyelination in the spine was clearly visible in the tractography of spine and MRI performed showed improvement in baseline and subcortical regions of the brain after the therapy. The patients were also scored using expanded disability status scale. The scores obtained before and after the treatment showed remarkable improvement in muscle power, bulk, and tone after the hESC therapy. Neither of the patients reported any AEs following the hESC therapy ${ }^{86}$ Further follow-up studies are required to be done with patients treated with hESCs to evaluate their use. Since the use of stem cell treatments for patients with MS is at a much earlier stage of development, it is not yet carried out routinely and treatment protocols have not been standardized. Treatment may be available through a clinical trial or, rarely, outside a trial if the clinical need is clear. ${ }^{89}$ Prior to our studies to treat MS with hESC, there is no study reporting the management of chronic MS in humans with hESC therapy.

\section{Conclusion}

Stem cell therapy is undoubtedly one of the remarkable achievements in medical history. This technology has revolutionized the laboratory cell biology and will provide much improved cell culture models for discovery and development of drugs, and fundamental studies of the genetic basis of disease. hESC therapy with its unique properties has shown promising results to treat complex neurological disorders like MS for which other cellular therapies have failed. MS, which is considered an incurable and lifelong disability, can be cured with hESC treatment.

\section{Acknowledgment}

The author acknowledges Knowledge Isotopes Pvt. Ltd. (http://www.knowledgeisotopes.com) for the medical writing assistance.

\section{Disclosure}

The author reports no conflicts of interest in this work.

\section{References}

1. Ruff C, Wilcox J, Fehlings MG. Current Status of Stem Cell Treatments for Cerebral Palsy: A Guide for Patients, Families and Caregivers. Spring; 2011:1-6. Available from: http://www.neurodevnet.ca/sites/ default/files/neurodevnet/download/stem\%20cell\%20newsletter_eng. pdf.
2. Zhang SC, Duncan ID. Remyelination and restoration of axonal function by glial cell transplantation. Prog Brain Res. 2000;127: 515-533.

3. Douvaras P, Wang J, Zimmer M, et al. Efficient generation of myelinating oligodendrocytes from primary progressive multiple sclerosis patients by induced pluripotent stem cells. Stem Cell Reports. 2014;3(2):250-259.

4. Ljungman P, Bregni M, Brune M, et al. Allogeneic and autologous transplantation for haematological diseases, solid tumours and immune disorders: current practice in Europe 2009. Bone Marrow Transplant. 2010;45(2):219-234.

5. Chen B, Zhou M, Ouyang J, et al. Long-term efficacy of autologous haematopoietic stem cell transplantation in multiple sclerosis at a single institution in China. Neurol Sci. 2012;33(4):881-886.

6. Kemp K, Hares K, Mallam E, Heesom KJ, Scolding N, Wilkins A. Mesenchymal stem cell-secreted superoxide dismutase promotes cerebellar neuronal survival. J Neurochem. 2010;114(6):1569-1580.

7. Rice CM, Kemp K, Wilkins A, Scolding NJ. Cell therapy for multiple sclerosis: an evolving concept with implications for other neurodegenerative diseases. Lancet. 2013;382(9899):1204-1213.

8. Stem cells in MS. Available from: http://www.nationalmssociety. org/Research/Research-News-Progress/Stem-Cells-in-MS. 2017. Accessed May 20, 2017.

9. Fan X, Wang JZ, Lin XM, Zhang L. Stem cell transplantation for spinal cord injury: a meta-analysis of treatment effectiveness and safety. Neural Regen Res. 2017;12(5):815-825.

10. Lu P. Stem cell transplantation for spinal cord injury repair. Prog Brain Res. 2017;231:1-32.

11. Kantake M, Hirano A, Sano M, et al. Transplantation of allogeneic adipose-derived mesenchymal stem cells in a cerebral palsy patient. Regen Med. 2017;12(5):575.

12. Muraro PA, Martin R, Mancardi GL, Nicholas R, Sormani MP, Saccardi R. Autologous haematopoietic stem cell transplantation for treatment of multiple sclerosis. Nat Rev Neurol. 2017;13(7):391-405.

13. Freed CR, Greene PE, Breeze RE, et al. Transplantation of embryonic dopamine neurons for severe Parkinson's disease. $N$ Engl J Med. 2001;344(10):710-719.

14. Ozolek JA, Jane EP, Esplen JE, et al. In vitro neural differentiation of human embryonic stem cells using a low-density mouse embryonic fibroblast feeder protocol. Methods Mol Biol. 2010;584:71-95.

15. Meamar R, Nematollahi S, Dehghani L, et al. The role of stem cell therapy in multiple sclerosis: an overview of the current status of the clinical studies. Adv Biomed Res. 2016;5:46.

16. Nat R, Nilbratt M, Narkilahti S, Winblad B, Hovatta O, Nordberg A. Neurogenic neuroepithelial and radial glial cells generated from six human embryonic stem cell lines in serum-free suspension and adherent cultures. Glia. 2007;55(4):385-399.

17. Phillips BW, Horne R, Lay TS, Rust WL, Teck TT, Crook JM. Attachment and growth of human embryonic stem cells on microcarriers J Biotechnol. 2008;138(1):24-32.

18. Minagar A, Jy W, Jimenez J, Alexander JS. Multiple sclerosis as a vascular disease. Neurol Res. 2006;28(3):230-235.

19. Confavreux C, Vukusic S, Moreau T, Adeleine P. Relapses and progression of disability in multiple sclerosis. $N$ Engl $J$ Med. 2000;343(20):1430-1438.

20. Sawcer S, Hellenthal G, Pirinen M, et al. Genetic risk and a primary role for cell-mediated immune mechanisms in multiple sclerosis. Nature. 2011;476(7359):214

21. Sarkar P, Rice CM, Scolding NJ. Cell therapy for multiple sclerosis. CNS Drugs. 2017;31(6):453-469.

22. Rolak LA. MS: the basic facts. Clin Med Res. 2003;1(1):61-62.

23. Roth E. The history of multiple sclerosis: how far have we come? Healthline. December 12, 2016.

24. Xiao J, Yang R, Biswas S, et al. Neural stem cell-based regenerative approaches for the treatment of multiple sclerosis. Mol Neurobiol. Epub 2017 May 2. 
25. Clanet M, Radue E, Kappos L, et al. A randomized, double-blind, dose-comparison study of weekly interferon $\beta-1 \mathrm{a}$ in relapsing MS. Neurology. 2002;59(10):1507-1517.

26. Pithadia A, Jain S, Navale A. Pathogenesis and treatment of multiple sclerosis (MS). Int J Neurol. 2009;10(2):1-20.

27. Sloka J, Stefanelli M. The mechanism of action of methylprednisolone in the treatment of multiple sclerosis. Mult Scler. 2005;11(4):425-432.

28. Berger JR, Koralnik IJ. Progressive multifocal leukoencephalopathy and natalizumab - unforeseen consequences. $N$ Engl $J$ Med. 2005;353(4):414-416.

29. Grade S, Bernardino L, Malva JO. Oligodendrogenesis from neural stem cells: perspectives for remyelinating strategies. Int J Dev Neurosci. 2013;31(7):692-700.

30. Owens GM, Olvey EL, Skrepnek GH, Pill MW. Perspectives for managed care organizations on the burden of multiple sclerosis and the cost-benefits of disease-modifying therapies. J Manag Care Pharm. 2013;19(1 Supp A):S41-S53.

31. Naci H, Fleurence R, Birt J, Duhig A. Economic burden of multiple sclerosis. Pharmacoeconomics. 2010;28(5):363-379.

32. Multiple sclerosis by the numbers: facts, statistics, and you. Available from: http://www.healthline.com/health/multiple-sclerosis/factsstatistics-infographic. Accessed September 20, 2017.

33. Hartung DM, Bourdette DN, Ahmed SM, Whitham RH. The cost of multiple sclerosis drugs in the US and the pharmaceutical industry: Too big to fail? Neurology. 2015;84(21):2185-2192.

34. Sykes M, Nikolic B. Treatment of severe autoimmune disease by stem-cell transplantation. Nature. 2005;435(7042):620.

35. Trapp BD, Peterson J, Ransohoff RM, Rudick R, Mörk S, Bö L. Axonal transection in the lesions of multiple sclerosis. N Engl J Med. 1998;338(5):278-285.

36. Joshi DC, Zhang C-L, Lin T-M, et al. Deletion of mitochondrial anchoring protects dysmyelinating shiverer: implications for progressive MS. J Neurosci. 2015;35(13):5293-5306.

37. How Much Do Stem Cell Treatments Really Cost? Available from: http://www.ipscell.com/2015/02/stemcelltreatmentcost/. Accessed September 20, 2017.

38. Stem cell therapy in India. Available from: http://www.tour2india4health. com/Stem-Cell-Therapy-in-India.html. Accessed September 20, 2017.

39. Tappenden P, Saccardi R, Confavreux C, et al. Autologous haematopoietic stem cell transplantation for secondary progressive multiple sclerosis: an exploratory cost-effectiveness analysis. Bone Marrow Transplant. 2010;45(6):1014-1021.

40. Arruda LC, de Azevedo JT, de Oliveira GL, et al. Immunological correlates of favorable long-term clinical outcome in multiple sclerosis patients after autologous hematopoietic stem cell transplantation. Clin Immunol. 2016;169:47-57.

41. Fassas A, Kazis A. High-dose immunosuppression and autologous hematopoietic stem cell rescue for severe multiple sclerosis. J Hematother Stem Cell Res. 2003;12(6):701-711.

42. Knapton S. Miracle' stem cell therapy reverses multiple sclerosis. Science News. 2015.

43. Yamout B, Hourani R, Salti H, et al. Bone marrow mesenchymal stem cell transplantation in patients with multiple sclerosis: a pilot study. J Neuroimmunol. 2010;227(1):185-189.

44. Fitzner D, Simons M. Chronic progressive multiple sclerosis pathogenesis of neurodegeneration and therapeutic strategies. Curr Neuropharmacol. 2010;8(3):305-315.

45. Alvarez-Buylla A, Lim DA. For the long run: maintaining germinal niches in the adult brain. Neuron. 2004;41(5):683-686.

46. Thiruvalluvan A, Czepiel M, Kap YA, et al. Survival and functionality of human induced pluripotent stem cell-derived oligodendrocytes in a nonhuman primate model for multiple sclerosis. Stem Cells Transl Med. 2016;5(11):1550-1561.

47. Liu K, Song Y, Yu H, Zhao T. Understanding the roadmaps to induced pluripotency. Cell Death Dis. 2014;5(5):e1232.

48. Lu X, Zhao T. Clinical therapy using iPSCs: hopes and challenges. Genomics Proteomics Bioinformatics. 2013;11(5):294-298.
49. Zhao T, Zhang Z-N, Rong Z, Xu Y. Immunogenicity of induced pluripotent stem cells. Nature. 2011;474(7350):212-215.

50. Zhao T, Zhang ZN, Westenskow PD, et al. Humanized mice reveal differential immunogenicity of cells derived from autologous induced pluripotent stem cells. Cell Stem Cell. 2015;17(3):353-359.

51. Ardeshiry Lajimi A, Hagh MF, Saki N, Mortaz E, Soleimani M, Rahim F. Feasibility of cell therapy in multiple sclerosis: a systematic review of 83 studies. Int J Hematol Oncol Stem Cell Res. 2013;7(1): 15-33.

52. Brüstle O, Jones KN, Learish RD, et al. Embryonic stem cell-derived glial precursors: a source of myelinating transplants. Science. 1999;285(5428):754-756.

53. Billon N, Jolicoeur C, Tokumoto Y, Vennström B, Raff M. Normal timing of oligodendrocyte development depends on thyroid hormone receptor alpha 1 (TR $\alpha 1)$. EMBO J. 2002;21(23):6452-6460.

54. Aharonowiz M, Einstein O, Fainstein N, Lassmann H, Reubinoff B, Ben-Hur T. Neuroprotective effect of transplanted human embryonic stem cell-derived neural precursors in an animal model of multiple sclerosis. PloS One. 2008;3(9):e3145.

55. Xu RH, Chen X, Li DS, et al. BMP4 initiates human embryonic stem cell differentiation to trophoblast. Nat Biotechnol. 2002;20:1261-1264.

56. Gerami-Naini B, Dovzhenko O, Durning M, Wegner FH, Thomson JA, Golos TG. Trophoblast differentiation in embryoid bodies derived from human embryonic stem cells. Endocrinology. 2004;145:1517-1524.

57. Clark AT, Bodnar MS, Fox M, et al. Spontaneous differentiation of germ cells from human embryonic stem cells in vitro. Hum Mol Genet. 2004;13:727-739.

58. Wu JQ, Habegger L, Noisa P, et al. Dynamic transcriptomes during neural differentiation of human embryonic stem cells revealed by short, long, and paired-end sequencing. Proc Natl Acad Sci U S A. 2010;107(11):5254-5259.

59. Noisa P, Raivio T, Cui W. Neural progenitor cells derived from human embryonic stem cells as an origin of dopaminergic neurons. Stem Cells Int. 2015;2015:647437.

60. Liu Y, Wang L, Kikuiri T, et al. Mesenchymal stem cell-based tissue regeneration is governed by recipient $\mathrm{T}$ lymphocytes via IFN-gamma and TNF-alpha. Nat Med. 2011;17(12):1594-1601.

61. Kawakami Y, Li M, Matsumoto T, et al. SDF-1/CXCR4 axis in Tie2lineage cells including endothelial progenitor cells contributes to bone fracture healing. J Bone Miner Res. 2015;30(1):95-105.

62. Borlongan CV, Glover LE, Tajiri N, Kaneko Y, Freeman TB. The great migration of bone marrow-derived stem cells toward the ischemic brain: therapeutic implications for stroke and other neurological disorders. Prog Neurobiol. 2011;95(2):213-228.

63. Shyu WC, Lee YJ, Liu DD, Lin SZ, Li H. Homing genes, cell therapy and stroke. Front Biosci. 2006;11:899-907.

64. Chen J, Li Y, Katakowski M, et al. Intravenous bone marrow stromal cell therapy reduces apoptosis and promotes endogenous cell proliferation after stroke in female rat. $J$ Neurosci Res. 2003;73(6):778-786.

65. Taguchi A, Soma T, Tanaka H, et al. Administration of CD34+ cells after stroke enhances neurogenesis via angiogenesis in a mouse model. J Clin Invest. 2004;114(3):330-338.

66. Kurozumi K, Nakamura K, Tamiya T, et al. Mesenchymal stem cells that produce neurotrophic factors reduce ischemic damage in the rat middle cerebral artery occlusion model. Mol Ther. 2005;11(1):6-104.

67. Vendrame M, Gemma C, de Mesquita D, et al. Anti-inflammatory effects of human cord blood cells in a rat model of stroke. Stem Cells Dev. 2005;14(5):595-604.

68. Lee ST, Chu K, Jung KH, et al. Anti-inflammatory mechanism of intravascular neural stem cell transplantation in haemorrhagic stroke. Brain. 2008;131(Pt 3):616-629.

69. Banerjee S, Williamson DA, Habib N, Chataway J. The potential benefit of stem cell therapy after stroke: an update. Vasc Health Risk Manag. 2012;8:569-580.

70. Wang X, Kimbrel EA, Ijichi K, et al. Human ESC-derived MSCs outperform bone marrow MSCs in the treatment of an EAE model of multiple sclerosis. Stem Cell Reports. 2014;3(1):115-130. 
71. Shroff G. Compositions comprising human embryonic stem cells and their derivatives, methods of use, and methods of preparation. Google Patents EP2422796 A3; 2007 Mar 6.

72. House of Lords SATSC. Available from: http://www.parliament.uk/ documents/lords-committees/science-technology/RegenerativeMedicine/RegenMed.pdf. Accessed September 15, 2017.

73. Mitalipova MM, Rao RR, Hoyer DM, et al. Preserving the genetic integrity of human embryonic stem cells. Nat Biotechnol. 2005;23(1):19-20.

74. Hovatta O, Mikkola M, Gertow K, et al. A culture system using human foreskin fibroblasts as feeder cells allows production of human embryonic stem cells. Hum Reprod. 2003;18(7):1404-1409.

75. Catalina $\mathrm{P}$, Bueno $\mathrm{C}$, Montes R, et al. Genetic stability of human embryonic stem cells: a first-step toward the development of potential hESC-based systems for modeling childhood leukemia. Leuk Res. 2009;33(7):980-990.

76. Shroff G. Establishment and characterization of a neuronal cell line derived from a 2-cell stage human embryo: clinically tested cell-based therapy for neurological disorders. Int J Recent Sci Res. 2015;6(4):3730-3738.

77. Shroff G, Vatsa D. Cell viability of human embryonic stem cells stored for a period of 9 years. Exp Clin Transplant. 2017;15(3):344-349.

78. Yang G, Mai Q, Li T, Zhou C. Derivation of human embryonic stem cell lines from single blastomeres of low-quality embryos by direct plating. J Assist Reprod Genet. 2013;30(7):953-961.

79. Geens M, Mateizel I, Sermon K, et al. Human embryonic stem cell lines derived from single blastomeres of two 4-cell stage embryos. Hum Reprod. 2009;24(11):2709-2717.

80. Strelchenko N, Verlinsky O, Kukharenko V, Verlinsky Y. Morula-derived human embryonic stem cells. Reprod Biomed Online. 2004;9(6):623-629.

81. Shroff G H-SP. Use of human embryonic stem cells in the treatment of Parkinson's disease: a case report. Int J Emerg Ment Health. 2015;17(3): 661-663.

82. Shroff G. Clinical effect of human embryonic stem cells therapy in two cases of cerebral palsy. J Neurol Res. 2015;5(3):230-232.

83. Shroff G, Barthakur J. Safety of human embryonic stem cells in patients with terminal conditions. Ann Neurosci. 2015;22(3):132-138.

84. Shroff G. Human embryonic stem cells in the treatment of patients with traumatic brain injury. SOJ Neurol. 2015;2(2):1-4.

85. Shroff G. A novel approach of human embryonic stem cells therapy in treatment of Friedreich's ataxia. IJCRI. 2015;6(5):261-266.

86. Shroff G. Human embryonic stem cell for the treatment of multiple sclerosis: a case report. CRINT. 2015;4:38-42.

87. Shroff G. Human embryonic stem cells in the treatment of autism: a case series. Innov Clinl Neurosci. 2017;14(3-4):12.
88. Shroff G. Morphogenesis of human embryonic stem cells into mature neurons under in vitro culture conditions. World J Exp Med. 2016;6(4):72.

89. Stem cell therapy. MS Trust; 2017. Available from: https://www. mstrust.org.uk/a-z/stem-cell-therapy. Accessed September 20, 2017.

90. Heffernan C, Sumer H, Guillemin GJ, Manuelpillai U, Verma PJ. Design and screening of a glial cell-specific, cell penetrating peptide for therapeutic applications in multiple sclerosis. PloS One. 2012;7(9): e45501.

91. Payne NL, Sun G, Herszfeld D, et al. Comparative study on the therapeutic potential of neurally differentiated stem cells in a mouse model of multiple sclerosis. PLoS One. 2012;7(4):e35093.

92. Nicaise AM, Banda E, Guzzo RM, et al. iPS-derived neural progenitor cells from PPMS patients reveal defect in myelin injury response. Exp Neurol. 2017;288:114-121.

93. Donegà M, Giusto E, Cossetti C, Schaeffer J, Pluchino S. Systemic injection of neural stem/progenitor cells in mice with chronic EAE. $J$ Vis Exp. 2014;(86).

94. Al Jumah MA, Abumaree MH. The immunomodulatory and neuroprotective effects of mesenchymal stem cells (MSCs) in experimental autoimmune encephalomyelitis (EAE): a model of multiple sclerosis (MS). Int J Mol Sci. 2012;13(7):9298-9331.

95. Connick P, Kolappan M, Crawley C, et al. Autologous mesenchymal stem cells for the treatment of secondary progressive multiple sclerosis: an open-label phase 2 a proof-of-concept study. Lancet Neurol. 2012;11(2):150-156

96. Cristofanilli M, Harris VK, Zigelbaum A, et al. Mesenchymal stem cells enhance the engraftment and myelinating ability of allogeneic oligodendrocyte progenitors in dysmyelinated mice. Stem Cells Dev. 2011;20(12):2065-2076.

97. Shroff G, Barthakur J. Safety and efficacy of human embryonic stem cells for the treatment of cerebrovascular accident: a case series. Glob $J$ Med Res. 2015;15(2).

98. Shroff G, Hopf-Seidel P. Use of human embryonic stem cells in the treatment of Parkinson's disease: a case report. Int J Emerg Ment Health. 2015;17:661-663.

99. Shroff G. Human embryonic stem cells in the treatment of spinocerebellar ataxia: a case series. J Clin Case Rep. 2015;5:1.

100. Shroff G, Gupta A, Barthakur JK. Therapeutic potential of human embryonic stem cell transplantation in patients with cerebral palsy. J Transl Med. 2014;12(1):318.

101. Shroff G. Transplantation of human embryonic stem cells in patients with multiple sclerosis and Lyme disease. Am J Case Rep 2016;17:944-949.
Stem Cells and Cloning: Advances and Applications

\section{Publish your work in this journal}

Stem Cells and Cloning: Advances and Applications is an international peer-reviewed, open access journal. Areas of interest in stem cell research include: Embryonic cell stems; Adult stem cells; Blastocysts; Cordblood stem cells; Stem cell transformation and culture; Therapeutic cloning; Umbilical cord blood and bone marrow cells; Laboratory,

\section{Dovepress}

animal and human therapeutic studies; Philosophical and ethical issues related to stem cell research. This journal is indexed on CAS. The manuscript management system is completely online and includes a quick and fair peer-review system. Visit http://www.dovepress.com/ testimonials.php to read real quotes from published authors. 